
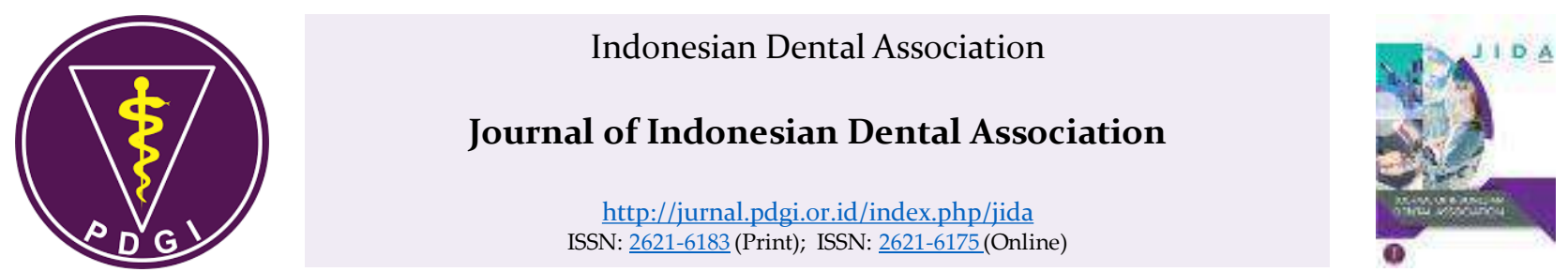

Research Article

\title{
The Effect of Red Beetroot Juice (Beta vulgaris, sp.) on the Tooth Color
}

\author{
Selviana Wulansari ${ }^{1}$, Gabriela Lintang Cristandy ${ }^{2 \S}$, Tien Suwartini ${ }^{1}$ \\ ${ }^{1}$ Department of Conservative Dentistry, Faculty of Dentistry, Trisakti University, Indonesia \\ 2 Undergraduate student, Faculty of Dentistry, Trisakti University, Indonesia
}

Received date: December 20, 2018. Accepted date: March 26, 2019. Published date: April 30, 2019.

\section{KEYWORDS}

color changes;

staining;

teeth;

vita easyshade $v$

ABSTRACT

Introduction: Tooth discoloration is one of the problems and the reason why people begin to notice the appearance of their teeth. Phenolic compounds are often found in foods and beverages, one of them is red beetroot juice that cause discoloration on the tooth surface. The acidity of red beetroot juice is a factor of color changes on the tooth surface extrinsicly. Objectives: This study aims to determine the effect of red beetroot juice on color changes of tooth surface. Methods: This experimental laboratory research conducted pretest and posttest. Twenty maxillary premolar samples within inclusion criteria were stored in the artificial saliva at $37^{\circ} \mathrm{C}$ and treated for 30 minutes using $50 \mathrm{~mL}$ red beetroot juice, followed by immersion in artificial saliva overnight. Treatment was repeated 7 times for 7 days consecutively. The teeth was tested by using Vita Easyshade $\mathrm{V}$ before and after treatment and then the acquired data was statistical tested using paired T-test. Result: T-test showed variable E, C and H with $\mathrm{p}=0.000(\mathrm{p}<0.05)$ showed a significant changes in total color deviation, chroma and hue, while the variable of $\mathrm{L}$ with $\mathrm{p}=0.015$ ( $\mathrm{p}>0.05)$ meant no significant change of value. Conclusion: It can be concluded that red beetroot juice (Beta vulgaris, $s p$ ) can affect color changes on the tooth surface.
\end{abstract}

\footnotetext{
${ }^{\S}$ Corresponding Author

E-mail address: gabrielalc.2105@gmail.com (Cristandy CL)
} 


\section{KATA KUNCI \\ perubahan warna; pewarnaan; \\ gigi; \\ Vita Easyshade V}

\begin{abstract}
ABSTRAK
Pendahuluan: Perubahan warna gigi merupakan salah satu masalah dan menjadi alasan sehingga orang mulai memperhatikan penampilan giginya. Senyawa fenolik sering ditemukan dalam makanan dan minuman, salah satunya yang berasal dari jus umbi bit merah, menjadi salah satu penyebab perubahan warna permukaan gigi. Selain itu, kadar keasaman yang terdapat pada jus umbi bit merah menjadi faktor yang menyebabkan terjadinya perubahan warna pada permukaan gigi secara ekstrinsik. Tujuan: Penelitian ini bertujuan untuk mengetahui adanya pengaruh dari jus umbi bit merah terhadap perubahan warna permukaan gigi. Metode: Penelitian ini merupakan uji eksperimental laboratorik yang dilakukan pada fase pre-test dan post-test. Dua puluh sampel premolar maksila disimpan dalam saliva buatan di dalam inkubator pada suhu $37^{\circ} \mathrm{C}$ dan direndam dalam $50 \mathrm{~mL}$ jus bit merah selama 30 menit, diikuti dengan perendaman dalam saliva buatan semalam. Perlakuan diulangi 7 kali selama 7 hari berturut-turut. Vita Easyshade V digunakan untuk menentukan warna gigi, termasuk Hue (H), Lightness (L), Chroma (C), dan Color (E) sebelum dan sesudah perawatan. Data dianalisis menggunakan paired T-test. Hasil: Uji parametrik $\mathrm{T}$ menunjukkan nilai variabel warna $\mathrm{E}, \mathrm{C}$ dan $\mathrm{H}$ dengan $\mathrm{p}=0,000(\mathrm{p}<0,05)$ yang menunjukkan adanya perubahan signifikan pada total deviasi warna, chroma dan hue, sementara nilai variabel L dengan $\mathrm{p}=0,015$ ( $\mathrm{p}>0,05)$ menunjukkan bahwa tidak ada perubahan signifikan pada nilai value. Kesimpulan: Dapat disimpulkan bahwa ada pengaruh jus umbi bit merah (Beta vulgaris, $s p$ ) terhadap perubahan warna permukaan gigi.
\end{abstract}

\section{PENDAHULUAN}

Sejak dahulu, banyak masyarakat Indonesia mengkonsumsi jus buah-buahan, sayur sayuran dan umbi-umbian. Tingkat konsumsi jus buah segar siap minum di Indonesia 3 tahun belakangan ini cukup fluktuatif. Tahun 2013 tingkat penetrasi pasar jus buah siap minum sebesar 18,3 persen, setahun kemudian turun menjadi 16,6\%. Tahun 2015 kembali meningkat dengan persentase sebesar $17,2 \% .^{1}$ Jus tersebut dikonsumsi karena masyarakat mempercayai tingkat antioksidan yang tinggi di dalamnya dapat menyehatkan tubuh. Terdapatnya antioksidan yang alami (seperti senyawa fenolik) maupun sintetis dapat melindungi dari kerusakan, menahan oksidasi lipid, menjaga dari berubahnya unsur organik di bahan makanan sehingga mampu memperlama umur simpan. ${ }^{2}$ Saat mempertahankan tubuh dari serangan radikal bebas, antioksidan berguna untuk menstabilkan radikal bebas dengan mencukupi kekurangan elektron dari radikal bebas sehingga dapat menghalangi berlangsungnya reaksi berantai. $^{3}$

Senyawa fenolik banyak ditemukan pada tumbuhan yang dikonsumsi maupun tidak dikonsumsi. Senyawa tersebut mempunyai banyak efek yang menguntungkan, termasuk efek antioksidan. ${ }^{4}$ Warna merah yang pekat pada umbi bit merah berasal dari konsentrasi tinggi betanin, yaitu salah satu pigmen betalain. Betalain merupakan suatu grup dari metabolisme kedua senyawa fenolik dari tumbuhan. Betalain digunakan sebagai pewarna makanan yang natural oleh industri pabrik makanan, tetapi mulai banyak menerima perhatian karena kemungkinan efek yang baik pada manusia, terlebih pada efek antioksidan dan efek antiinflamasi. ${ }^{5,6}$
Masyarakat di era sekarang ini berusaha memperbaiki tampilan wajahnya demi mendapatkan penampilan yang cantik, antara lain dengan memiliki gigi yang tampak putih. Perubahan warna gigi merupakan salah satu alasan orang mulai memperhatikan penampilan giginya. Perubahan warna pada gigi bervariasi mulai dari penyebabnya, lokasi, keparahan dan perlekatan bahan tumpat pada struktur gigi. ${ }^{7}$

Penyebab perubahan warna ekstrinsik dapat dibagi menjadi dua kategori, antara lain: (1) Senyawa yang bergabung bersama pelikel dan menghasilkan pewarnaan yang merupakan hasil dari warna dasar; (2) Bahan-bahan yang menyebabkan pewarnaan sebagai hasil dari interaksi kimia pada permukaan gigi. Selain itu, perubahan warna pada gigi secara ekstrinsik pada umumnya diklasifikasikan berdasarkan dari penyebabnya, baik metal maupun non metal. ${ }^{8}$

Pewarnaan secara langsung mempunyai banyak faktor etiologi dengan kromogen yang berasal dari sumber asupan makanan atau bahan yang secara rutin diletakkan dalam mulut. Senyawa kromogen organik tersebut diambil oleh pelikel dan warna yang dihasilkan oleh warna natural dari kromogen. Merokok dan mengunyah tembakau telah diketahui sebagai penyebab pewarnaan, seperti juga minuman teh dan kopi. Warna yang terlihat pada gigi diperkirakan berasal dari senyawa polifenol yang memberikan warna pada makanan. ${ }^{9}$

Beberapa penelitian menunjukkan bahwa minuman berpigmen tinggi dengan $\mathrm{pH}$ rendah (seperti teh hitam dan wine) menyebabkan perubahan warna pada gigi secara ekstrinsik. ${ }^{10,11}$ Derajat keasaman yang tinggi dan pigmen yang tinggi pada minuman seperti kopi dan wine 
juga dapat menyebabkan penguraian struktur keras gigi, seperti email gigi. ${ }^{12}$ Warna dan stabilitas pigmen betalain yang tinggi pada umbi bit merah, berada pada $\mathrm{pH}$ di antara 3-7. ${ }^{13}$ Derajat keasaman umbi bit merah yang tinggi, yaitu $\mathrm{pH}$ di bawah 5,5 (pH kritis), tidak hanya mengganggu integritas permukaan enamel secara klinis, namun juga meningkatkan kemungkinan perubahan warna gigi akibat adanya kadar pigmen yang tinggi pada makanan atau minuman. ${ }^{10}$

Dokter gigi harus mengerti mekanisme pewarnaan gigi dan relevansinya untuk memberikan pelayanan terbaik pada pasien. Informasi tersebut penting dalam proses penegakkan diagnosis dan rencana terapi pasien tersebut. Pencegahan terhadap penyebab perubahan warna gigi yang dapat dihindari sangatlah penting, dokter gigi dapat memberikan saran kepada teman sejawat mengenai terapi alternatif dari kasus ini. Pengetahuan mengenai proses patologis yang berhubungan dengan perubahan warna gigi dapat membantu dalam menjelaskan penyebab dari perubahan warna pada gigi kepada pasien yang gelisah atau prihatin terhadap keadaan giginya.

\section{BAHAN DAN METODE}

Dua puluh sampel gigi yang dikumpulkan pada bulan September - Oktober 2017 digunakan untuk sampel penelitian, diberi tanda berupa nomor urut dengan menggunakan cat kuku merek OPI bewarna ungu dan disimpan dalam tabung yang berisi saliva buatan yang diperoleh dari laboratorium Biokimia Universitas Indonesia untuk berada kondisi tetap basah seperti keadaan dalam mulut, kelembaban dan menghindari dehidrasi (Gambar 1).

Sebanyak 1400 gram umbi bit merah yang digunakan untuk 7 hari (umbi bit merah di jus sebanyak 200 gram setiap hari) dibersihkan terlebih dahulu dari tanah dan kotoran, lalu dipotong menjadi empat bagian. Umbi bit merah dimasukkan ke dalam juicer dengan merek Heles yang telah dinyalakan sebelumnya tanpa diberi air agar diperoleh jus umbi bit merah murni. Dari 200 gram umbi bit merah didapatkan sekitar $100 \mathrm{~mL}$ jus umbi bit merah dengan $\mathrm{pH}$ 5,5-5,8 (diukur sebelumnya menggunakan $\mathrm{pH}$ meter digital merek ATC) yang ditampung dalam wadah bervolume $250 \mathrm{~mL}$. Setelah itu diambil $50 \mathrm{~mL}$ jus umbi bit merah untuk perendaman. Umbi bit merah dijus setiap hari agar bahan untuk penelitian selalu segar. Sebelum dilakukan perendaman pada hari pertama, warna sampel diukur menggunakan alat VITA Easyshade V (diproduksi oleh VITA di negara Amerika Utara), lalu dicatat.

Sampel gigi dimasukkan ke dalam wadah gelas, selanjutnya jus umbi bit merah sebanyak $50 \mathrm{~mL}$ dituang, sehingga gigi terendam selama 30 menit. Perendaman 30 menit setara dengan minum dua gelas jus umbi bit merah dengan hitungan lama minum satu gelas jus selama 15 menit. Setelah dilakukan perendaman, gigi dimasukkan ke dalam saliva buatan semalam untuk menjaga gigi tetap dalam kondisi basah (Gambar 2). Perendaman diulang dan dilakukan selama 7 hari berturut-turut pada suhu $37^{\circ} \mathrm{C}$ untuk mensimulasikan keadaan di dalam mulut. Jus umbi bit merah dan saliva buatan diganti dengan yang baru setiap kali akan dilakukan perendaman. Pengukuran warna kembali pada hari ke-7 menggunakan alat VITA Easyshade V, lalu hasilnya dicatat. (Gambar 3).

\section{HASIL}

Data yang didapat dari penelitian ini adalah data numerik yang diuji terlebih dahulu dengan menggunakan uji normalitas Shapiro-Wilk. Hasil uji normalitas Shapiro-Wilk menunjukkan bahwa data tersebut terdistribusi normal karena nilai $\mathrm{p}$ sebelum dan sesudah adalah $\mathrm{p}>0,05$. Selanjutnya hasil uji $\mathrm{T}$ berpasangan terdapat pada Tabel 1. Pada Tabel 1, terlihat nilai variabel E, C, H (deviasi warna dari gigi, chroma dan hue) sesudah perlakuan lebih tinggi daripada sebelum perlakuan. Nilai Sig. (2-tailed) bernilai 0,00 yang berarti nilai $\mathrm{p}<0,05$ dimana perubahan nilai variabel $\mathrm{E}, \mathrm{C}$ dan $\mathrm{H}$ signifikan Kesimpulan yang didapat adalah ada perbedaan yang signifikan antara sebelum
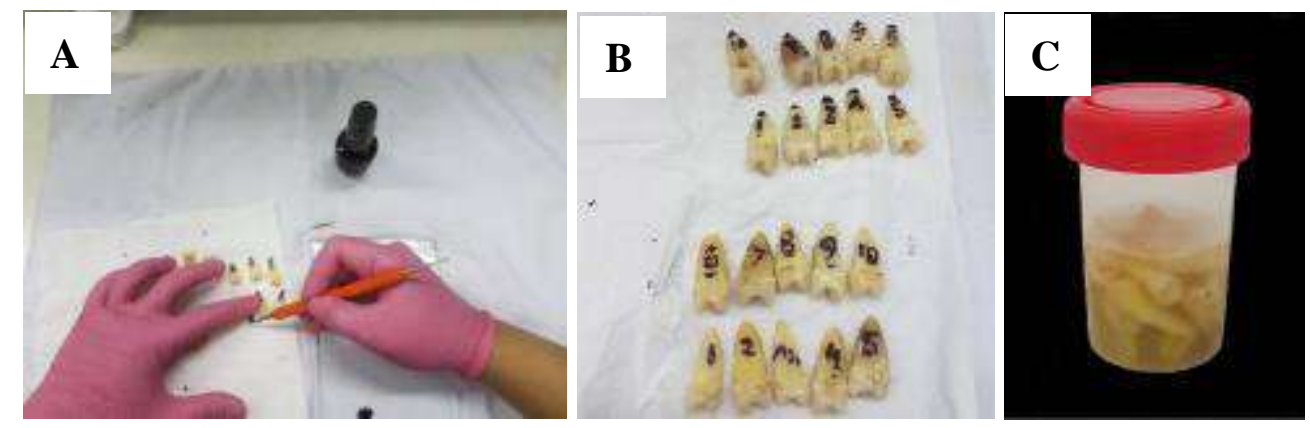

Gambar 1. (A) Tahap Persiapan Gigi; (B) Penomoran gigi premolar; (C) Gigi yang telah diberi nomor direndam pada dalam saliva buatan 
dan sesudah perlakuan jus umbi bit merah (Beta vulgaris, $s p$ ) terhadap sampel pada variabel E, C dan H. Terlihat juga dimana nilai sesudah perlakuan dari nilai L ( Value) tersebut menjadi lebih rendah dari sebelum perlakuan. Nilai Sig. (2-tailed) variabel $\mathrm{L}$ bernilai 0,015 yang berarti nilai $\mathrm{p}>0,05$ dimana perubahan nilai $\mathrm{L}$ tersebut tidak signifikan. Kesimpulan yang didapat adalah tidak ada perbedaan signifikan antara sebelum dan sesudah perlakuan jus umbi bit merah (Beta vulgaris, $s p$ ) terhadap sampel pada variabel L. Perhitungan selisih rata-rata sesudah dan sebelum perlakuan (Tabel 2) untuk mencari $\Delta \mathrm{E}, \Delta \mathrm{L}, \Delta \mathrm{C}$, dan $\Delta \mathrm{H}$ tertulis pada Tabel 2. Tabel 2 menunjukan bahwa $\Delta \mathrm{E}$ bernilai 3,930 yang berarti terdapat deviasi warna, $\Delta \mathrm{L}$ bernilai $-2,075$ yang berarti warna sampel setelah diberi perlakuan menjadi semakin gelap, $\Delta \mathrm{C}$ bernilai 4,380 menunjukkan warna sampel setelah diberi perlakuan menjadi semakin tersaturasi, dan $\Delta \mathrm{H}$ bernilai $-2,510$ yang berarti warna sampel gigi setelah diberi perlakuan menjadi condong ke arah warna merah

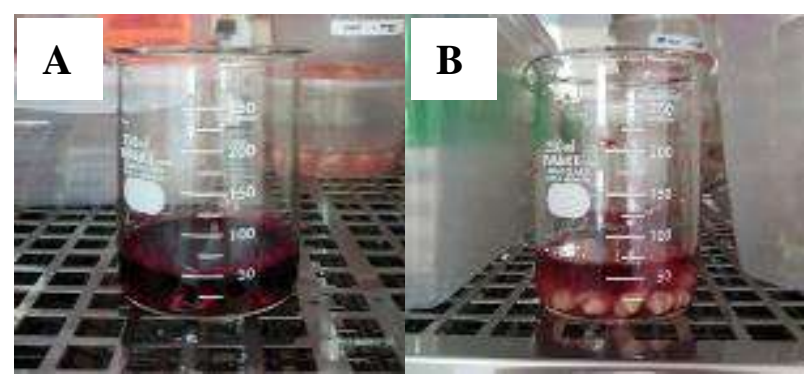

Gambar 2. (A) Tahap perlakuan; (B) Direndam dengan jus umbi bit merah selama 30 menit Direndam dengan saliva buatan kembali semalam setelah direndam dalam jus umbi bit merah

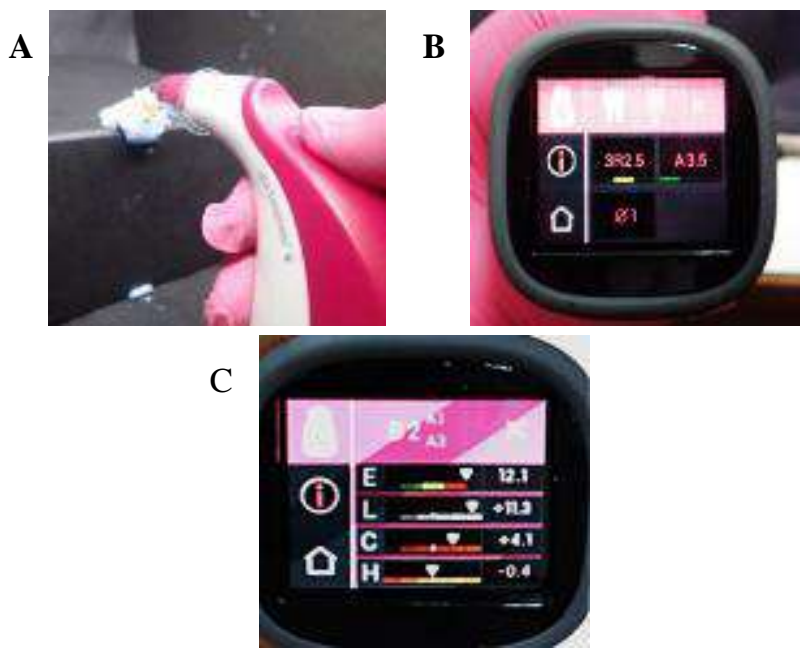

Gambar 3. (A) Tahap pengamatan; (B) Pengukuran warna gigi menggunakan Vita Easyshade V; (C) Data yang ditunjukan di dalam Vita Easyshade V
Tabel 1. Hasil Uji T Berpasangan Sebelum dan Sesudah Perlakuan

\begin{tabular}{cccc}
\hline Variabel & $\begin{array}{c}\text { Rata-Rata } \\
\text { Sebelum } \\
\text { Perlakuan }\end{array}$ & $\begin{array}{c}\text { Rata-Rata } \\
\text { Sesudah } \\
\text { Perlakuan }\end{array}$ & $\begin{array}{c}\text { Sig. (2- } \\
\text { tailed) }\end{array}$ \\
\hline E & $3,935 \pm 2,440$ & $7,865 \pm 3,615$ & 0,000 \\
L & $0,203 \pm 2,690$ & $-0,045 \pm 2,952$ & 0,015 \\
C & $2,150 \pm 2,435$ & $6,530 \pm 3,925$ & 0,000 \\
H & $-1,525 \pm 1,677$ & $-4,035 \pm 1,962$ & 0,000 \\
\hline
\end{tabular}

Tabel 2. Total Selisih dari Rata-Rata Sesudah dan Sebelum Perlakuan

Variabel $\begin{gathered}\text { Total Selisih Rata-Rata Sesudah } \\ \text { dan Sebelum Perlakuan }\end{gathered}$

\begin{tabular}{cc}
\hline$\Delta \mathrm{E}$ & 3,930 \\
$\Delta \mathrm{L}$ & $-2,075$ \\
$\Delta \mathrm{C}$ & 4,380 \\
$\Delta \mathrm{H}$ & $-2,510$ \\
\hline
\end{tabular}

\section{PEMBAHASAN}

Berdasarkan hasil penelitian, terlihat adanya perbedaan yang signifikan yang bervariasi pada variabel E, C dan H. Perbedaan yang tidak signifikan terlihat pada variabel L. Tabel 1 menunjukkan bahwa ada perbedaan nilai variabel $\mathrm{E}, \mathrm{C}$ dan $\mathrm{H}$ yang signifikan dari sebelum dan sesudah perlakuan. Selain itu, terdapat perbedaan nilai variabel $\mathrm{L}$ walaupun tidak signifikan dari sebelum dan sesudah perlakuan menggunakan jus umbi bit merah selama 7 hari berturut-turut. Setelah perlakuan selama 7 hari, Nilai variabel $\mathrm{E}$ yang merupakan nilai total dari deviasi warna gigi dari hasil penelitian menjadi lebih tinggi. Hal ini memperlihatkan bahwa jus umbi bit merah mempengaruhi dan membuat nilai total dari deviasi warna gigi semakin tinggi dan berubah secara signifikan. Nilai variabel L yang menunjukan value / kecerahan gigi dari hasil penelitian menjadi semakin lebih rendah. Kondisi ini menunjukan bahwa perlakuan dengan menggunakan jus umbi bit merah mengurangi tingkat kecerahan gigi (value) walaupun perubahan kecerahan gigi tersebut tidak signifikan. Selain itu, nilai dari variabel C yang menunjukkan chroma / kepekatan gigi dari hasil penelitian sesudah perlakuan dengan jus umbi bit merah menjadi semakin lebih tinggi dari sebelum perlakuan. Kondisi ini menunjukan bahwa jus umbi bit merah dapat meningkatkan kepekatan / chroma dari warna gigi sehingga perubahan kepekatan warna gigi 
(chroma) sangat bermakna. Nilai variabel $\mathrm{H}$ yang menunjukan nilai hue dari hasil penelitian sesudah perlakuan dengan jus umbi bit merah menjadi semakin rendah dari nilai sebelum dilakukan perlakuan. Hal ini menunjukkan bahwa jus umbi bit merah membuat perubahan signifikan pada hue dari warna gigi sehingga semakin rendah dan condong lebih bewarna merah dari sebelumnya. ${ }^{14}$

Pada penelitian sebelumnya, nilai $\Delta \mathrm{E}$ lebih kecil daripada 1, maka secara umum perubahan warna tidak teridentifikasi oleh pengamat, jika $\Delta \mathrm{E}$ berada diantara 1 dan 3,3 maka perubahan warna dapat teridentifikasi oleh pengamat namun secara umum perubahan masih dapat diterima. Jika nilai $\Delta \mathrm{E}$ diatas 3,3 maka perubahan warna dapat teridentifikasi oleh pengamat dan tidak dapat diterima sehingga perlu dilakukan penggantian restorasi estetik atau dalam kasus ini diperlukan prosedur bleaching untuk mengembalikan warna asli gigi. ${ }^{15}$

Hasil penelitian pada Tabel 2 menunjukkan bahwa $\Delta \mathrm{E}$ pada warna gigi sampel penelitian sebesar 3,930. Nilai $\Delta \mathrm{E}$ hasil penelitian yang lebih dari 3,3 tersebut mengindikasikan perlunya untuk dilakukan prosedur bleaching untuk mengembalikan warna gigi seperti semula sehingga didapatkan warna gigi dengan estetika yang baik. ${ }^{16}$ Selain itu terlihat pula $\Delta \mathrm{L}$ yang bernilai 2,075 yang berarti bahwa warna sampel gigi yang diuji menjadi semakin lebih gelap. Delta C bernilai 4,380 menunjukkan bahwa sampel gigi setelah diberi perlakuan menjadi lebih tersaturasi. Terlihat pula $\Delta \mathrm{H}$ yang bernilai 2,510 , menunjukan bahwa warna sampel gigi setelah diberi perlakuan dengan jus umbi bit merah menjadi lebih condong ke arah warna merah.

Penelitian ini juga menggunakan inkubator yang diatur suhunya pada suhu $37^{\circ} \mathrm{C}$ secara konstan seperti yang dilakukan juga oleh penelitian sebelumnya demi mendapatkan suhu yang sama seperti di dalam mulut. ${ }^{16}$ Kotak boks dengan dasar berwarna hitam dengan lampu LED 7,3 watt digunakan dalam karena warna hitam merupakan warna netral yang tidak mempunyai hue (disebut juga warna achromatic), merupakan warna tergelap dan mempunyai kecenderungan untuk menyerap cahaya yang terlihat. ${ }^{17}$ Selain itu, warna hitam digunakan untuk mensimulasikan keadaan seperti di dalam mulut. ${ }^{18}$ Penelitian ini menggunakan spektrofotometer karena pengukuran menggunakan alat ini menunjukkan keakuratan yang tinggi sampai $82 \%$ jika dibandingkan dengan menggunakan colorimeter yang keakuratannya hanya mencapai $70 \% .{ }^{19}$ Ruang warna CIELCH (Commission Internationale de l'Eclairage $\mathrm{L}, \mathrm{C}, \mathrm{H}$ ) digunakan di dalam penelitian ini dimana CIELCH mempunyai toleransi warna yang mendekati persepsi mata manusia. Hal ini akan mengurangi ketidaksepahaman antara pengamat dan nilai yang ditunjukkan oleh alat. Kesepahaman yang ditunjukkan oleh alat dengan mata manusia pada color space CIELCH sebesar 85\%. Jauh lebih baik daripada color space CIELab (Commission Internationale de l'Eclairage $\left.\mathrm{L}^{*}, \mathrm{a}^{*}, \mathrm{~b}^{*}\right)$ yang kesepahamannya hanya mencapai $75 \% .{ }^{17}$ Pemilihan ini dilakukan dengan tujuan untuk mencegah adanya variabel-variabel gangguan yang mungkin dapat mengubah hasil pada analisis warna. Penelitian ini juga menggunakan perhatian khusus pada pemilihan gigi. Gigi yang digunakan merupakan gigi yang baik dimana belum pernah dilakukan restorasi sebelumnya dan tidak ada retak pada permukaan labial dari gigi serta belum pernah ditambal sebelumnya. Lokasi analisis warna juga ditentukan pada daerah sepertiga tengah dari mahkota. Penelitian lain juga menggunakan daerah sepertiga tengah gigi sebagai lokasi untuk melakukan evaluasi perubahan warna. ${ }^{15}$ Pengukuran warna dilakukan tiga kali dengan poin aktif dari spektrofotometri berada di tengah-tengah dari sepertiga tengah mahkota gigi pada setiap sampel dan selanjutnya alat spektrofotometri yakni Vita Easyshade $V$ merata-rata tiga kali pembacaan pada setiap sampel secara otomatis dimana rata-rata yang didapat digunakan untuk analisis data. ${ }^{16}$

Perubahan warna gigi yang dibaca menggunakan Vita Easyshade $V$ dengan sistem CIELCH pada sampel penelitian ini disebabkan oleh zat betanin yang terkandung di dalam umbi bit merah disertai dengan suasana asam yang disebabkan oleh rendahnya kadar $\mathrm{pH}$ pada jus umbi bit merah yakni berkisar antara 5,5-5,8. ${ }^{12}$ Pada saat $\mathrm{pH}$ dalam mulut menjadi rendah, kadar keasaman tersebut akan menginduksi permukaan gigi menjadi semakin kasar sehingga betanin yang merupakan senyawa warna kromogenik dari umbi bit merah mudah masuk dan menempel dalam permukaan gigi sehingga dapat menyebabkan perubahan warna ekstrinsik pada gigi. Sesuai dengan penelitian lain yang telah dilakukan yang mengatakan bahwa peningkatan kekasaran pada permukaan gigi akan meningkatkan kerentanan terhadap pigmen-pigmen dari luar. ${ }^{20,21}$ Penggunaan saliva buatan pada penelitian ini sebenarnya dapat membantu mengurangi kerentanan gigi dari pewarnaan karena adanya potensi efek remineralisasi. Tetapi proses remineralisasi ini tidak signifikan sehingga efek perubahan warna pada permukaan gigi terlihat jelas. ${ }^{15}$

Pigmen warna pada umbi bit merah mempunyai kadar pigmen yang tinggi pada jus umbi bit merah dan menjadi faktor utama penyebab terjadinya perubahan warna pada permukaan gigi yang signifikan. Pigmen warna yang berperan dalam proses perubahan warna ini adalah betanin, suatu pigmen warna yang masuk ke dalam golongan betalain dan merupakan gabungan warna antara betaxanthin dan betacyanin. ${ }^{22}$ Umbi bit merah yang memiliki kadar betanin sebanyak 300-600 mg/kg, betacyanin $840-900 \quad \mathrm{mg} / \mathrm{kg}$ mempunyai aktivitas antioksidan yang tinggi dan sangat mudah larut dalam air. $^{23,24}$ 
Berbagai cara dapat dilakukan untuk mencegah terjadinya perubahan warna pada permukaan gigi. Menurut penelitian sebelumnya salah satu cara untuk mencegah perubahan warna pada permukaan gigi adalah dengan tidak menyikat gigi setelah makan makanan/minuman asam. ${ }^{15}$ Menyikat gigi sesaat setelah makan makanan/minuman asam dapat meningkatkan kekasaran enamel yang disebabkan oleh rendahnya $\mathrm{pH}$ makanan yang dapat menyebabkan demineralisasi. Membersihkan gigi dengan cara menyikat gigi dapat dilakukan 1 jam setelah makan/minum asam saat $\mathrm{pH}$ keadaan mulut mulai kembali normal. Setelah mengkonsumsi makanan dan minuman berwarna, berkumur - kumur dengan air juga menjadi salah satu cara untuk mencegah perubahan warna gigi karena sifat pigmen-pigmen dalam umbi bit merah yang larut dalam air. ${ }^{25}$ Penggunaan sedotan saat mengkonsumsi minuman berwarna dapat menjadi salah satu tambahan dalam pencegahan terjadinya perubahan warna gigi. Penghentian konsumsi makanan dan minuman atau kebiasaan-kebiasaan yang berkontribusi dalam perubahan warna gigi dapat mencegah terjadinya staining lebih lanjut. ${ }^{26}$

\section{KESIMPULAN}

Dari hasil penelitian ini, dapat disimpulkan bahwa terdapat perubahan warna yang signifikan pada permukaan gigi setelah gigi diberi perlakuan dengan jus umbi bit merah selama 7 hari. Hasil penelitian menunjukkan bahwa jus umbi bit merah menyebabkan pewarnaan karena kandungan pigmen kromogen serta kandungan senyawa polifenol yang tinggi diikuti dengan rendahnya $\mathrm{pH}$ umbi bit merah yang ikut berperan serta dalam demineralisasi permukaan gigi.

\section{KONFLIK KEPENTINGAN}

Tidak ada konflik kepentingan dalam penelitian ini.

\section{DAFTAR PUSTAKA}

1. Pratiwi W. Nilai bisnis industri jus buah ready to drink lebih dari 8 triliun rupiah. MARS. 2015 Agustus [Diakses pada tanggal 18 Mei 2017] Tersedia dari: http://www.marsindonesia.com/news letter/nilai-bisnis-industri-jus-buah-ready-drink-lebih -dari-8-triliun-rupiah

2. Rohdiana D. Aktivitas daya tangkap radikal polifenol dalam daun teh. Majalah Jurnal Indonesia. 2001;12, 53-8.

3. Windono T, Soediman S, Yudawati U, Ermawati E, Srielita, Erowati TI. Uji peredam radikal bebas terhadap 1,1-Diphenyl-2-Picrylhydrazyl (DPPH) dari ekstrak kulit buah dan biji anggur (Vitis vinifera L.) Probolinggo biru dan Bali. Artocarpus. 2001;1, 3443
4. Halliwell B, Murcia MA, Chirico S, Aruoma OI. Free radicals and antioxidants in food and in vivo: what they do and how they work. London: Taylor and Francis Online. 2009, 7-20.

5. Georgiev VG, dkk. Antioxidant activity and phenolic content of betalain extracts from intact plants and hairy root cultures of the red beetroot Beta vulgaris cv. Detroit dark red. Plant Foods for Human Nutrition. 2010;65 (2), 105-11.

6. Zielinska-Przyjemska M, Olejnik A, DobrowolskaZachwieja A, Grajek W. In vitro effects of beetroot juice and chips on oxidative metabolism and apoptosis in neutrophils from obese individuals. Phytotherapy Research. 2009;23 (1), 49-55

7. Wilkins EM. Dental stains and discoloration in: Clinical practice of the dental hygienist, edisi 10. Philadelphia: Lippincott Williams \& Wilkins. 2009; 285-9

8. Gorlin RJ, Goldman HM. Environmental pathology of the teeth in: Thoma's oral pathology. 6th ed.Vol. I, , St. Louis:CV Mosby Co; 2011 pp. 184-92

9. Jacobs MB. The chemical analysis of foods and food products. New York: Robert E Krieger Publishing; 2013. p. 140

10. Joiner A, dkk. Adsorption from black tea and red wine onto in vitro salivary pellicles studied by ellipsometry. European Journal of Oral Sciences. 2003;111:4 17-22.

11. Proctor GB, dkk. Salivary proteins interact with dietary constituents to modulate tooth staining. Journal of Dental Research 2005;84:7 3-8.

12. Azer SS, Hague AL, Johnston WM. Effect of $\mathrm{pH}$ on tooth discoloration from food colorant in vitro. J Dent. 2010;38 Suppl 2:e106-9.

13. Attia GY, Moussa MEM, Sheashea ER. Characterization of red pigments extracted from red beet (Beta vulgaris, sp.) and its potential uses as antioxidant and natural food colorants. Egypt: $J$. Agric. Res.; 2013. 91(3)

14. Vita Easyshade. [Diakses pada tanggal 21 Juli 2017] Tersedia di: https://www.vita-zahnfabrik.com/pdb _GG2G50G200_en.html

15. Pirolo R, Mondeli RFL, dkk. Effect of coffee and a cola-based soft drink on the color stability of bleached bovine incisors considering the time elapsed after bleaching. Journal of Applied Oral Science. 2014;22(6):534-540.

16. Fontes ST, dkk. Color stability of a nanofill composite: effect of different immersion. Journal of Applied Oral Science. 2009;17(5):388-391.

17. Pantone $\mathrm{x}$-rite. A guide to understanding color. Pantone. 2016; 19-21 [diakses pada tanggal 18 Desember 2017] Tersedia dari URL www.xrite.com

18. Poggio C, Vialba L, Berardengo A, Federico R, Colombo M, Beltrami R, et al. Color stability of new esthetic restorative materials: a spectrophotometric analysis. J Funct Biomater. 2017;8(3):1-8. 
19. Gehrke P, Riekeberg U, Fackler O, Dhom G. Comparison of in vivo visual, spectrophotometric and colorimetric shade determination of teeth and implant-supported crowns. Int $\mathbf{J}$ Comput Dent. 2009;12(3):247-63.

20. Prasetyo EA. Keasaman minuman ringan menurunkan kekerasan permukaan gigi. Maj Ked Gigi. 2005;38(2):60-3.

21. Dahl JE, Pallesen U. Tooth bleaching--a critical review of the biological aspects. Crit Rev Oral Biol Med. 2003;14(4):292-304.

22. Patel DN, Kerr AR. Tooth discoloration clinical presentation. Medscape; 2015.

23. Ananda L. Karakteristik fisikokimia serbuk bit merah (Beta vulgaris L.) yang diproses dengan variasi drying agents dan maltrodekstrin sebagai coating agent. Semarang: Unika Soegijapranata;
2008.

24. Anam C, Andriani MAM, Abdilah A. Pengaruh jenis dan konsentrasi bahan pengikat terhadap karakteristik fisik serta analisa aktivitas antioksidan tablet effervescent dari ekstrak buah beet (Beta vulgaris). Jurnal Teknosains Pangan. 2013:2(2):3944.

25. Patel DN, Kerr AR. Tooth discoloration treatment and management. Medscape. 2015

26. Wijayadharma A. Pengaruh konsumsi teh hijau dan teh hitam kemasan celup terhadap pewarnaan pada permukaan gigi [Skripsi]. Jakarta: Fakultas Kedokteran Gigi Universitas Trisakti.

27. Prasetyo EA. Keasaman minuman ringan menurunkan kekerasan permukaan gigi. Surabaya: Maj Ked Gigi. 2005;38(2):60-3. 